\title{
Accounting Lecturer's Perception On Academic Cheating
}

\author{
Soeparlan Pranoto ${ }^{1}$, Erry Andhaniwati ${ }^{2}$, Invony Dwi Aprilisanda ${ }^{3}$ \\ \{pranoto@upnjatim.ac.id ${ }^{1}$,invony.aprilisanda.ak@upnjatim.ac.id ${ }^{3}$ \} \\ ${ }^{1,2,3}$ Universitas Pembangunan Nasional Veteran Jawa Timur, 081938586481 ${ }^{1}$, 081339366660 , \\ Indonesia
}

\begin{abstract}
This study discusses the perception of accounting lecturers about academic cheating from the perspective of the main task (Tridharma) as an obligation. Lecturers' perceptions of academic cheating are reviewed from Kohlberg's Moral Development Theory and Decision Making based on Gender Theory. This study uses a qualitative method. There were 6 informants. The results showed that there were two informants at level 6, indicated by the choice of conscience decisions according to personal principles, they combined beliefs in accordance with conscience and religious teachings. From the research it can be concluded that male and female informants can play roles according to their position according to gender theory. There is no difference of opinion in taking appropriate action to prevent them from committing fraud in the academic field.
\end{abstract}

Keywords: academic cheating, gender, moral development, dysfunctional behavior.

\section{Introduction}

The reality of education in Indonesia has not been quite successful in creating good moral. Universities are less serious in reducing academic cheating, it is an ironic problem in Indonesia, many research on academic cheating conducted by lecturers and students. If academic fraud continues to be conducted, academic fraud will probably have an impact in the workplace, and fraudulent behaviour is regarded as an acceptable alternative because there are no obvious legal sanctions, so the behaviour tends to be Various situations and other conditions,

The lecturer certification process is fraudulent such as document counterfeiting and writing plagiarism such as scientific journals and books. The majority of higher education institutions known to be dishonest come from private colleges [1].

Other case about academic fraud is happened in Bandung Katolik Parahyangan University fired professor, has acknowledged his writings titled "RI as a New Middle Power?, cheating Australian article titled" The Middle Power Concept in Australian Foreign Policy ". Finally, Prof. Anak Agung Banyu Perwita also has submitted a resignation letter from Unpar [2]. Faculty of Economics and Business Anggito Abimanyu, has submitted his resignation as a lecturer of UGM. The petition was delivered Abimanyu related to charges of plagiarism Articles writing in a national newspaper. Anggito Accused of plagiarizing papers Hotbonar Sinaga and Munawar Kasan. Writing on behalf of Abhimanyu was aired on February 10, 2014 and titled idea Disaster Insurance. Officially Reporters at UC UGM on Monday. 
Plagiarism is considered to be a serious transgression in the academic world. Due to the perception that plagiarism is rampant among both students and lecturers, the Indonesian government has established policies to prevent plagiarism in academia. Varieties of sanctions, ranging from score reduction to the revocation of granted academic titles have been applied to those who are caught committing this serious academic offense [3] The study explains that plagiarism is one of act academic fraud that is considered the most serious in the world of academia.

Higher education should function in developing capabilities, forming a broad mindset and good behavior. Education builds a dignified civilization and is useful to educate the life of the nation, develop human potential to become human beings who believe and fear God, moral, healthy, knowledgeable, insightful, creative, and Independent. Higher Education must also give examples of good ethics, Ethics is diminishing to become more abstract and losing its relevance to human life is a reality today, as in [4]

which states that Ethics is no longer about various ethical problems that must be faced by humanity but rather on moral words or language. Ethics is no longer related to "what is good", but to the problem of language, such as: "what does good mean?" Western philosophy. Contrary to western views, Eastern Philosophy emphasizes the spirit of communality.Ethics are diminishing to become more abstract and losing their relevance to human life is a reality today.

Ethical is behavior when someone can act in accordance with the laws, regulations, and morals that have been set. Ethical behavior should be applied in all fields of the profession, but the reality that occurs still occurs ethical deviations causing scandal in the profession. Many parties will be affected by the scandal that occurred in the profession, both those who have been involved in it and those who are preparing to enter the profession. the rise of scandals that occur in a professional field, then a crisis will arise. This crisis is finally called the professional ethical crisis [5], then it can be drawn a red line that ethics is needed by lecturers as good figures to set an example for students, lecturers' perceptions of academic cheating are very important to foster awareness as a limitation of what can and should not be done. According to [6] lecturers have a moral obligation to reduce cheating. It is important that educators attend to all factors known to deal with academic cheating.

The lecturers do not have to focus on external factors at the expense of internal factors. to reduce or eliminate cheating, lecturers must focus on internal factors. To combat the cheating epidemic, the thing that needs to be done is to change students' perceptions when getting lecturer goals. Specifically, lecturers need to find ways to make teaching pedagogical skills and knowledge provided to students [7].

Based on this background and previous studies above, researchers motivated to explore the perceptions of the professor of ethical accounting at the economics Faculty of UPN Veteran East Java. This study focused on understanding the lecturer on activities that give rise to academic fraud. The focus of this research is the decision on the aspect of psychology for the situation of followers activities that have been conducted by lecturers. So the purpose of this research can be missed, whether the background of academic cheating in higher education from the viewpoint of lecturers as educators. 


\section{Research Method}

The method used in this study is a qualitative method with an interpretive approach. The reason researchers use qualitative methods is because of a deeper understanding of the meaning of the individual and the process of the incident in detail, so that the dynamics of a social reality which influence each other from various aspects of life are known. and the researcher wants to explore how lecturers' perceptions interpret academic fraud (Academic Fraud) from an individual's point of view in terms of several theories. This study will assess lecturers understanding of some activities that can lead to cheating on the responsibilities of lecturers (tridharma) as well as the implementation of the lecturer code of ethics at the "Veteran" National Development University of East Java. Selection criteria as informants in this study were lecturers accounting faculty of economics and holds a maximum doctoral degree, and teaches courses which include ethics. Informants who fit the above criteria are 6 people.

The moral development of each person is related to life experiences during life. Moral development can be called a person's character education. Internal and external factors can be the background of one's perception of fraudulent activities in the environment. This research focuses on differences in understanding and roles by female and male lecturers in terms of Gender, Lawrence Kohlberg's Cognitive Moral Development Theory and lecturers' responsibilities towards Tridharma's assignments.

Data collection in this research as follows:

1. Lecturers supporting data in the accounting department at the faculty of economics

2. Attendance Data and Course Syllabus

3. Academic Guidebook for the academic year 2018/2019

4. Regulation of the Minister of National Education of the Republic of Indonesia Number 17 year 2010

5. Law Number 12 year 2012 concerning Higher Education

Process research conducted by collecting the required data, these data will be made some core questions and will develop according to the needs of the author. Interview questions are reviewed from several aspects. The observation was carried out for 2 weeks by paying attention to the activities of the informants on campus.

\section{Result and Discussion}

\section{Perceptions of Academic Cheating is reviewed by Lawrence Kohlberg's theory of moral development}

Explanation of the Lawrence Kohlberg stage:

First stage, acts that are motivated to avoid punishment.

second stage, actions that are motivated to get benefits or prizes

third stage, acts motivated to anticipate the reproach of others, is imagined hypothetically.

The fourth stage is the consideration of doing an action based on an understanding of social rules, laws and obligations, anticipating actions that can cause reproach and disgrace. 
The fifth stage, acts that are motivated to maintain respect for others and society on the basis of shared principles.

The sixth stage, actions motivated by self-blame for violating their own principles.

In this research, the researcher connects the academic guide book of 2018/2019 with informant's perception as a standard rule for the duties, responsibilities, obligations and rights of lecturers to carry out activities in higher education. From the interviews conducted by researchers that all informants ( 3 men and 3 women) showed that the informants did not belong to the criteria for the preconventional level (the first and second stage). Because at this stage a person was able to defend his decision based only on self-interest and the actions carried out just to avoid punishment.

From the results of the study it can be concluded that the lecturer as the informant has fulfilled his responsibilities and obligations professionally. the answers from all informants were in line with the researchers' expectations that the lecturer must have a code of ethics and obey the rules as reflected in the academic manuals. one of the informants with the initials "ER" said,

\footnotetext{
"Gak merasa berat karena merupakan tugas dan tanggung jawab saya daripada lembaga yang harus saya kerjakan atau laksanakan semampu saya sepenuh hati."
}

According to the answer from one of the informants who are able to represent some of the answers of the analysis unit indicates that the lecturers as educators do not feel heavy perform basic tasks (Tridharma Universities) because the task is an obligation that must be carried out, he also explained that the main tasks to be executed wholeheartedly.

At the conventional level that is at the third and fourth stages is individualism and purpose, this stage of moral reasoning is based on rewards (gifts) and self-interest. Children obey when they want and need to obey. What is true is what feels good and what is thought to result in a gift. according to the results of research on the analysis unit shows that all information is not based on the gifts received or reproach from the institution because of the failure that has been done.

Based on the theory of post-conventional level moral development (fifth and sixth stages), the results of the study showed that there were 2 (two) informants who were at the fifth stage. In the fifth stage, a person believes that doing something that is broadly correct in order to support public welfare. Actions are carried out based on principles agreed with the community for self-respect. Concern about efforts to maintain respect for fellow citizens. In the fifth stage one believes that by doing something right, then widely expected to support the general welfare. Actions taken based on the principles agreed upon by the community for the honor of self. according to the results of interviews conducted, one informant with the initials $\mathrm{SH}$ stated that universities need to provide ethics as provisions when students graduate and work as accountants.

$$
\begin{aligned}
& \text { "Lha itu perlu, harus di tanamkan dari sekarang apalagi ya nanti kan jurusan akuntansi kan } \\
& \text { produknya akuntan ya..ya kalau akuntan kalau tdk mempunyai etika apakah kinerja nya nanti } \\
& \text { dapat dipertanggung jawabkan, merupakan indikator menunjukkan kinerja yang baik" }
\end{aligned}
$$

According to researchers, lecturers as role models for their students. lecturers as educators must have broad insight and good ethics. the lecturer as the informant in this study has gone beyond the fifth stage of Kohlberg's theory. theory which explains that the informant has social morality as a value to himself in a society.

one of the informants who had reached stage six with the initials "AS" explained that 
"Ehhh memang suara hati itu adalah yang paling mendasar ya, karena itulah sebenarnya apa namanya, ehhh dia itu dilahirkan dengan karakteristik sendiri dengan suara hati sendiri, kadang logika ga masuk tapi suara hati bisa masuk ya. Karena kita dilahirkan sebagai manusia ya."

The sixth stage are universal ethical principles. At this stage a person has developed a moral standard based on universal human rights. When faced with a conflict between law and conscience, a person will follow a conscience, even though the decision may involve personal risk. the results of research conducted by researchers to analyze the attitude of informants in dealing with conflicts between professionalism and conscience according to the sixth stage of Kohlberg's moral development theory, according to researchers if there are informants who reach the sixth stage then this person is already at the stage of sacrifice in taking risks and decisions according to the heart conscience.

\section{Based on the Republic of Indonesia Law number 12 of 2012,}

informant in this study had different opinions about the functions of tertiary institutions, but some core points of perception of informants could be drawn which explained that lecturers must provide useful knowledge and good morals for their students, because all will be reflected in their future workplace. based on the Republic of Indonesia Law number 12 of 2012, each informant in this study had different opinions about the functions of tertiary institutions, but some core points of perception of informants could be drawn which explained that lecturers must provide useful knowledge and good morals for their students, because all will be reflected in their work later. interview quote from one informant with the initials "AS"

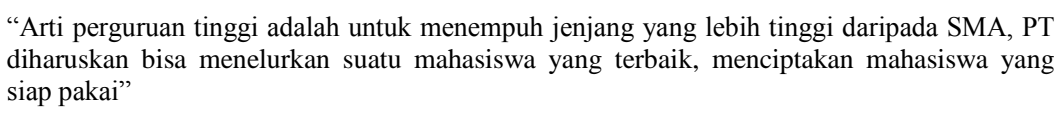

related to this law lecturers are also expected to be able to provide good role models in carrying out their duties, the task as a lecturer prone to fraud is the presence of attendance and demands to write (research), from interviews conducted by researchers there are informants who explain that there are several lecturers who are often late and absent when teaching even some have been entangled in cases of palgiarism.[8]

\section{Based on the meaning of gender}

According to Albrecht (2012:6), acts of cheating include all forms of human ingenuity in terms of design by forcing the will of individuals to gain profit through false statements. There are no rules in defining fraud, because it includes things that are shocking, fraudulent, cunning or ingenuity, as well as unfair ways. there are limits that are able to define fraud are things that can limit human dishonesty.

gender as an analytical concept is used to identify differences between men and women from several non-biological aspects which include psychological, social and cultural aspects. gender also has a role to identify feminine or masculine from someone [9] in this study shows there is no difference in perceptions about the activities of fraud that occur in higher education, even the informants can position themselves and play a role from a rational and emotional standpoint. informants as lecturers have many common perceptions about actions that can be called academic cheating. gender is also correlated with good leadership style in higher education. an informant argued that leaders should be in an institution must be able to 
protect and nurture the whole staff. a good leader and a high integrity control system will be able to minimize the fraud that will be committed by his employees.

\footnotetext{
" Betullllllll...iya lah, makanya sebagai seorang pemimpin itu kan ing ngarso sing tulado, ing madya mangun karso, tut wuri handayani. Makanya fraud itu terjadi karena keteladanan daripada kepemimpinan itu yang bisa dijadikan sebagai cerminan, dari penelitian robet Kaplan yang menciptakan balance score card $80 \%$ ketika perusahaan itu gagal itu yang salah bukan karyawannya..tapi leader, itu statement nya Robert Kaplan".
}

Based on the meaning of Dysfunctional Behaviour

Dysfunctional behavior is defined as deviant behavior. In the context of psychology, dysfunctional behavior is referred to as abnormality. Abnormalities or dysfunctional behavior is something that deviates from normal or is different from the typical, is a characteristic behavior that is determined subjectively, given to those who have rare or dysfunctional conditions [10]

Some conventional criteria for abnormalities: Distress, someone who displays depression, anxiety, unhappiness will be considered as showing abnormal behavior because their behavior arises because of distress [11]

all informants have the same answer in dealing with dysfunctional behavior. The informant will not tolerate any deviant actions in higher education either for students or lecturer.

\section{Acknowledgement}

We would like to thank we thank the accounting department for all the support both financially and encouragingly. thanks to all accounting lecturers who are willing to be informants to provide opinions and motivation. 


\section{References}

[1] T. Wahono, "No Title," edukasi.kompas, 2013. [Online]. Available: https://edukasi.kompas.com/read/2013/10/08/0954328/Sertifikasi.Dosen.di.400.Pergur uan.Tinggi.Diwarnai.Kecurangan.

[2] G. G. T. Tinular, "No Title," The Jakarta Post, 2010. [Online]. Available: https://edukasi.kompas.com/read/2013/10/08/0954328/Sertifikasi.Dosen.di.400.Pergur uan.Tinggi.Diwarnai.Kecurangan.

[3] I. B. Siaputra, "No Title," Int. J. Educ. Integr., vol. 9, no. 2, 2013.

[4] D. S. Pasande, "BUDAYA LONGKO' TORAJA DALAM PERSPEKTIF ETIKA LAWRENCE KOHLBERG," J. Filsafat, vol. 23, no. 2, 2013.

[5] M. Fitria and V. F. Sari, "PENGARUH ORIENTASI IDEALISME, RELATIVISME, TINGKAT PENGETAHUAN AKUNTANSI, DAN GENDER TERHADAP PERSEPSI MAHASISWA AKUNTANSI TENTANG KRISIS ETIKA AKUNTAN PROFESIONAL," J. Simp. Nas. Akunt., 2015.

[6] M. Roig, "On The Causes Of Academic Dishonesty," J. Eur. Med. Writ., vol. 15, no. 120-122, 2006.

[7] D. Purnamasari, "Faktor-faktor yang mempengaruhi kecurangan akademik pada mahasiswa," Educ. Psychol. J., 2013.

[8] DPR RI, Pendidikan Tinggi. Indonesia: Undang-Undang Republik Indonesia, 2012.

[9] S. Pektra and R. Kurnia, "Pengaruh Gender, Pengalaman Auditor, Dan Kompleksitas Tugas Terhadap Audit Judgement," Ultim. Account., 2015.

[10] S. K. Whitbourne and R. P. Halgin., Abnormal psychology: Clinical perspectives psychological disorders., 7th ed. New York: McGraw Hill, 2014.

[11] I. Yuhertiana, S. Pranoto, and H. Priono, "Perilaku disfungsional pada siklus penganggaran pemerintah: Tahap perencanaan anggaran," J. Akunt. Audit. Indones., 2015. 